\title{
APLIKASI PENGENALAN SHOLAT SUNNAH DAN JUZ'AMA DI MASJID ATTAQWA BERBASIS ANDROID
}

\author{
Zulkariski Mauladi ${ }^{1}$, Fanisya Alva Mustika ${ }^{2}$ Lukman $^{3}$ \\ Program Studi Teknik Informatika, Fakultas Teknik dan Ilmu Komputer, \\ Universitas Indraprasta PGRI \\ Jalan Raya Tengah No 80, Kelurahan Gedong, Pasar Rebo, Jakarta Timur \\ mzulkariski@gmail.com ${ }^{1}$, alva.mustika@gmail.com², 1kmnaja51@gmail.com ${ }^{3}$
}

\begin{abstract}
Abstrak
Penelitian ini bertujuan untuk mengenalkan bahwa Sholat Sunnah banyak macamnya, belum lagi dengan bagaimana tata cara pelaksanaanya dan juga surat apa saja yang di sarankan untuk dibaca saat pelaksaanya. Manfaat penelitian ini dapat meningkatkan wawasan pada anak-anak dan masyarakat dalam mengenal macam-macam Sholat Sunnah beserta tata cara pelaksanaannya yang efesien dengan penggunaan perangkat mobile android. Metode pada penelitian ini dilakukan dengan pengembangan metode SDLC (Software Development Life Cycle) pada model Waterfall. Lokasi penelitian di Kabupaten Bogor khususnya daerah Nanggerang, Masjid Attaqwa. Hasil dari penelitian ini bertambahnya wawasan mengenai macam-macam Sholat Sunnah baik pada peneliti dan pengguna dari pada aplikasinya nanti.
\end{abstract}

Kata Kunci: Android, Sholat Sunnah, Tata Cara, Pengenalan.

\begin{abstract}
This research aims to introduce that Sunnah Prayer is many kinds, not to mention with how the procedure of implementation and also what letters are recommended to be read when the execution. The benefits of this research can increase insights in children and the public in getting to know the various Sunnah Prayers and their efficient implementation procedures with the use of android mobile devices. The method in this research was carried out with the development of the SDLC (Software Development Life Cycle) method on the Waterfall model. The research location in Bogor Regency, especially Nanggerang area, At-taqwa Mosque. The results of this study increase insight into the various Sunnah Prayers both in researchers and users rather than the application later.
\end{abstract}

Keywords: Android, Sunnah Prayers, Procedures, Introduction.

\section{PENDAHULUAN}

Seiring dengan tingkat mobilitas yang tinggi, handphone yang semula hanya untuk media komunikasi sekarang bisa melebihi fungsi dasarnya, berbagai macam fitur sudah bisa dirasakan diberbagai handphone yang ada saat ini dari kamera, video, pengolah data, dokumen dan lain sebagainya. Android merupakan sistem operasi untuk telepon seluler yang berbasis Linux. Android menyediakan platform terbuka bagi para pengembang untuk menciptakan aplikasi mereka sendiri untuk digunakan oleh bermacam piranti bergerak (Nazruddin, 2012). Oleh karena itu banyak aplikasi-aplikasi yang diciptakan dengan berbasis Android. Aplikasi adalah alat terapan yang difungsikan secara khusus dan terpadu sesuai kemampuan yang dimilikinya (Sutabri, 2012). Namun pada aplikasi tuntunan sholat yang telah ada sebelumnya, user hanya dapat membaca dan mendengar bacaan-bacaan sholat dan melihat gambar saja. Dengan adanya masalah tersebut, maka dari itu peneliti akan membuat sebuah aplikasi mobile yang ringan dan bisa di gunakan pada seluruh telepon seluler android secara gratis. Tujuan pada penelitian ini untuk mempermudah pembelajaran dalam mengenal macam-macam tuntunan sholat sunnah yang akan disajikan dengan yang cara berbeda yaitu dengan menggabungkan basis multimedia, dimana user tidak hanya dapat membaca dan melihat gambar, tetapi user nantinya juga dapat mendengarkan bacaan-bacaan surat do'a dalam sholat, menonton video yang akan menampilkan gerakan tata cara shalat yang baik dan benar dengan efesien pada penggunaan perangkat mobile. Hasil yang akan di dapatkan pada penelitian ini adalah bertambahnya wawasan dalam mengenal macam-macam sholat sunnah beserta tuntunannya bagi peneliti dan pengguna dari aplikasi. Berdasarkan hal tersebut, peneliti tertarik 
membuat penelitian dengan judul "Pengenalan Macam-Macam Sholat Sunnah, Tata Cara dan Juz'ama Berbasis Android".

\section{PENELITIAN RELEVAN}

Penelitian relevan yang peneliti ambil yaitu penelitian yang di teliti oleh Hendy Cahya Lesmana, R. Rizal Isnanto, Eko Didik .W berjudul "Perancangan Aplikasi Android "SHOLAT YUKK" Sebagai Media Pembelajaran Ibadah Shalat Anak-Anak" dengan nomor ISSN: 2338-0403 pada tahun 2016, dimana pada penelitian ini menjelaskan bahwa motivasi pembelajaran yang mudah dan menarik dengan memanfaatkan teknologi dalam bidang agama islam, khususnya tata cara shalat. Maka dibuatlah aplikasi "SHOLAT YUKK" pada android sebagai media pembelajaran ibadah shalat untuk anak-anak (H. Cahya, Lesmana; R. Rizal, Isnanto; W. Didik, 2016).

Diambil dari penelitian oleh oleh Adhi Susano yang berjudul "Rancang Bangun Aplikasi Berbasis Android Untuk Pengolahan Data Pengurus Masjid", dimana salah satu yang menjadi fokus penelitian peneliti disini adalah Masjid Darussalam Kota Wisata yang terletak di daerah pemukiman elit Kota Wisata Cibubur (Susano, 2016).

Diambil dari penelitian oleh Beta Yolanda yang berjudul "Aplikasi Tuntunan Shalat Berbasis Android", dimana pada penelitian ini menjelaskan aplikasi yang dibuat oleh peneliti berbasis multimedia, sehingga user tidak hanya dapat membaca dan melihat gambar, tetapi user juga dapat mendengarkan bacaan-bacaan serta menonton video gerakan sholat yang dapat menampilkan gerakan sholat yang baik dan benar (Yolanda, 2017).

Di ambil dari penelitian oleh Joko Nuryanto yang berjudul "Aplikasi Shalat Pada Smartphone Berbasis Android", dimana dalam penelitian ini peneliti membahas tentang aplikasi shalat pada smartphone berbasis android menggunakan metodologi Rational Unified Process (RUP) (Nuryanto Joko, 2018).

\section{METODE PENELITIAN}

Metode pada penelitian ini dilakukan dengan menggunakan pengembangan metode SDLC (Software Development Life Cycle) pada model Waterfall. (Jogiyanto, 2010) Dengan pengembangan sistem pada metode ini didefinisikan sebagai aktifitas untuk menghasilkan sistem informasi berbasis komputer untuk menyelesaikan persoalan ataupun memanfaatkan kesempatan, dimana hal ini menggambarkan pendekatan yang sistematis dan juga berurutan pada pengembangan perangkat lunak. (Sugiyono, 2013) Suatu penelitian yang pada dasarnya merupakan cara ilmiah untuk mendapatkan data dengan tujuan dan kegunaan tertentu. Penelitian adalah terjemahan dari kata research, ada juga yang menerjemahkan research sebagai riset. Research itu sendiri berasal dari kata re yang berarti "kembali" dan to research yang berarti "mencari kembali" (Sumantri, 2011).

Peneliti juga menggunakan metode evaluasi dalam melakukan penelitian. Evaluasi adalah bentuk penelitian yang bertujuan untuk memeriksa proses perjalanan suatu program sekaligus menguraikan fakta-fakta yang bersifat kompleks dan terlibat didalam program (Mukhadis, 2016).

\section{Langkah-Langkah Perancangan Sistem}

\section{Analisa Kebutuhan}

Sebelum merancang sebuah sistem kita harus memahami kebutuhan pengguna. Langkahlangkah yang dilakukan pada tahap ini adalah:
a. Menentukan profile pengguna
b. Menganalisa task yang digunakan
c. Menganalisa data masukan
d. Menganalisa proses yang berjalan atau proses yang digunakan
e. Mengumpulkan kebutuhan-kebutuhan pengguna
f. Mencocokan kebutuhan tersebut dengan task

\section{Studi Kepustakaan}

Peneliti melakukan studi kepustakaan berdasarkan referensi dan berbagai diskusi pembahasan, baik dengan dosen pembimbing maupun dengan orang yang berkompeten pada kasus ini. Studi kepustakaan bertujuan untuk mempelajari dan memahami dasar teori yang berhubungan dengan analisa kebutuhan yang telah dilakukan. Selain itu peneliti juga melakukan studi dari 
berbagai media yang berupa diktat, modul, buku-buku, artikel-artikel, baik dari internet maupun media cetak untuk menunjang demi terselesaikannya tugas akhir ini.

\section{Perancangan Sistem}

Perancangan adalah sebuah kegiatan merancang dan menentukan cara mengolah sebuah sistem informasi dari hasil analisa sistem sehingga dapat memenuhi kebutuhan dari pengguna termasuk diantaranya perancangan user interface, data dan aktivitas proses (O'Brien dan Marakas, 2010). Langkah-langkah yang dilakukan dalam perancangan program ini adalah:

a. Merancang database

Dalam merancang sistem, database digunakan untuk menyimpan data-data yang telah diinput. Adapun tahapan dalam pembuatan database, yaitu:

1) Membuat tabel-tabel data beserta primary key

2) Melakukan relationship dari setiap tabel

3) Membuat query

4) Membuat report yang digunakan untuk menampilkan output.

b. Merancang interface

Dalam merancang interface atau tampilan ada beberapa hal yang harus diperhatikan oleh perancang tampilan, antara lain:

1) Harus memiliki jiwa seni (kreatif)

2) Mengerti selera pengguna secara umum

3) Melakukan dokumentasi rancangan agar dapat diubah dengan cara:

a) Memebuat sketsa pada kertas (storyboard)

b) Penjelasan keterkaitan jendela satu dengan yang lainnya

Selain itu dalam merancang antarmuka ada beberapa tahapan yang harus dilalui, yaitu:

1) Merancang menu utama beserta icon objek, view, dan representasi visual

2) Merancang tampilan untuk hasil output

c. Mengembangkan interface

Dalam melakukan pengembangan terhadap antar muka hal pertama yang harus kita perhatikan adalah membangun prototype. Dari prototype tersebut, perancang antar muka akan dapat mulai membangun antar muka secara utuh.

d. Melakukan validasi terhadap interface

Evaluasi adalah bagian penting dari proses pengembangan, untuk mengetahui bagaimana tenggapan pengguna terhadap antar muka yang telah dibuat. Evaluasi ini akan kita gunakan untuk memperbaiki kekurangan pada anatar muka yang telah terbangun. Anturan dalam perancangan antar muka:

1) Buatlah antar muka yang mudah dipahami dan dikuasai oleh pengguna

2) Buatlah antar muka yang konsisten

\section{Implementasi dan Evaluasi}

Implementasi adalah proses menterjemahkan dokumen hasil desain menjadi baris-baris perintah bahasa pemrograman komputer. implementasi bisa diartikan pelaksanaan atau penerapan. (Kirana, 2010) Semakin baik hasil analisis dan desain yang dilakukan, maka proses pengkodean ini akan lebih mudah dilakukan.

Evaluasi yang ditujukan sebagai bagian tahap terakhir perancangan sistem biasanya dimaksudkan untuk pembahasan. Evaluasi dilakukan disetiap tahap. Kerja sistem biasanya berulang, ketika peneliti menyelesaikan satu tahap pengembangan sistem akan berlanjut ke tahap berikutnya.

\section{Pengujian}

Pengujian pada perangkat lunak atau Software Testing merupakan suatu proses investigasi yang dilakukan untuk mendapatkan informasi mengenai kualitas dari suatu produk atau layanan yang sedang diuji, atau lebih spesifiknya software testing adalah proses mengeksekusi suatu program untuk menemukan bug (kesalahan atau cacat lainnya) dari perangkat lunak (Nanda Samsu Dhuha, 2018). Pengujian sangatlah penting dilakukan untuk menjamin kualitas sistem aplikasi, dan juga menjadi peninjauan terakhir terhadap spesifikasi, desain, dan pengkodean. 


\section{HASIL DAN PEMBAHASAN}

Dari hasil penelitian yang peneliti lakukan, maka peneliti dapat menganalisa permasalahan yang ada pada anak-anak maupun masyarakat dalam menambah wawawasan dengan banyaknya macam sholat sunnah. Adapun permasalahan yang ada adalah:

1. Anak-anak dan masyarakat saat ini membutuhkan sarana informasi yang cepat, mudah dan praktis terkait dengan pembelajran dalam mengenal macam-macam sholat sunnah beserta tuntunan tata caranya, dengan menggunakan perangkat mobile Android yang dimiliki.

2. Pada aplikasi tuntunan sholat yang telah ada sebelumnya, user hanya dapat membaca, mendengar bacaan-bacaan sholat dan melihat gambar saja, serta tidak memfokuskan pada banyaknya macam-macam sholat sunnah.

3. Tidak seperti penggunaan pada media buku sebagai sumber informasi yang dalam penggunaanya tidak efisien, seperti harus membacanya dengan informasi yg sudah ada di buku tanpa pembaharuan sesuai perkembangan pada saat ini atau kata lainnya update informasi sangat rumit, sehingga mengharuskan untuk mencari dan membeli lagi buku guna pembelajarannya yang lebih lanjut.

Program aplikasi ini akan dibuat dengan menggunakan bahasa pemograman java dan menggunakan database TinyDB. Data-data yang dikelola akan di simpan dalam database. Dengan penyimpanan data dalam database ini diharapkan mampu mempermudah dalam proses pencarian, penyimpanan dan pengolahan data dengan aman dan praktis. Aplikasi ini nantinya akan dapat di akses oleh semua masyarakat umum terutama kalangan anak muda hingga orang dewasa. Selain itu, aplikasi ini juga dapat di gunakan kapanpun dan di manapun atau tidak terkait dengan instansi manapun. Aplikasi ini dapat di akses 24 jam dan memiliki tampilan Interface yang mudah dipahami.

\section{Struktur Navigasi}

Struktur navigasi yang digunakan untuk membuat aplikasi pengenalan macam-macam sholat ini yaitu struktur navigasi campuran (composite). Berikut gambar dari struktur navigasinya :

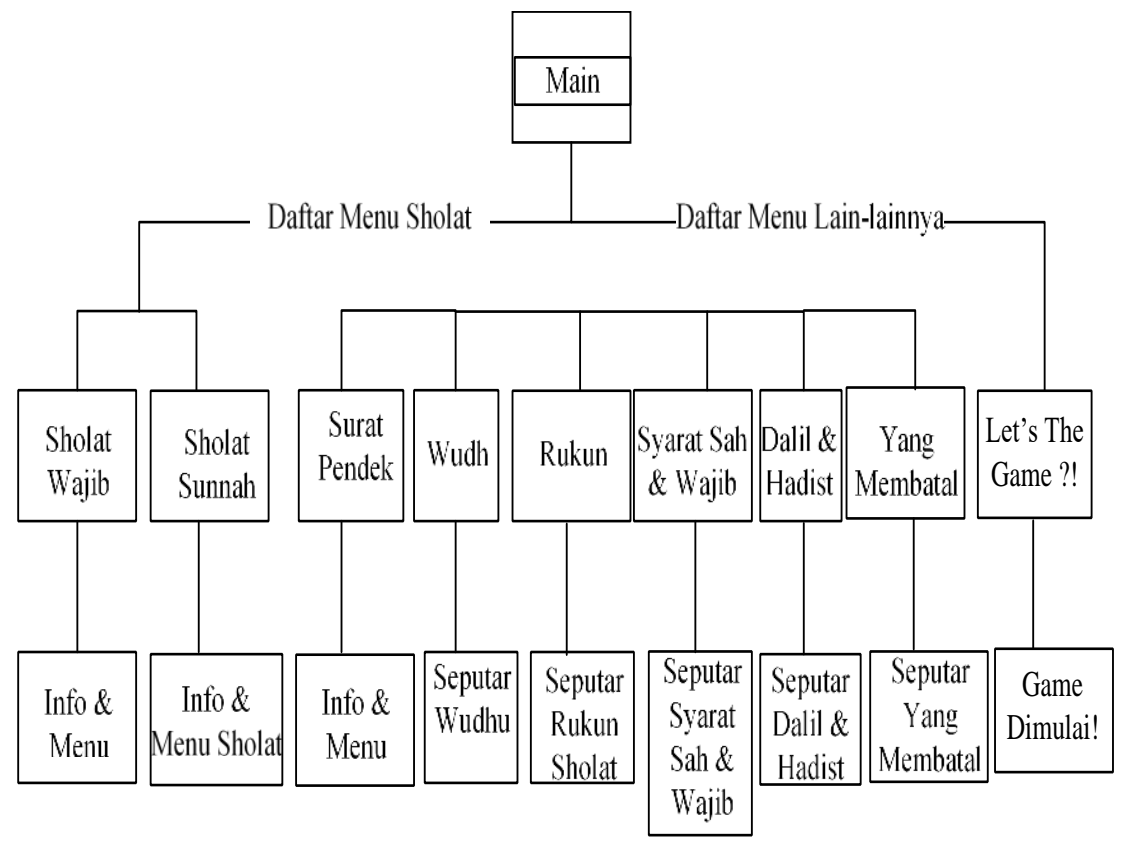

Gambar 1. Struktur Navigasi 


\section{Flowchart Pada Main Menu Utama}

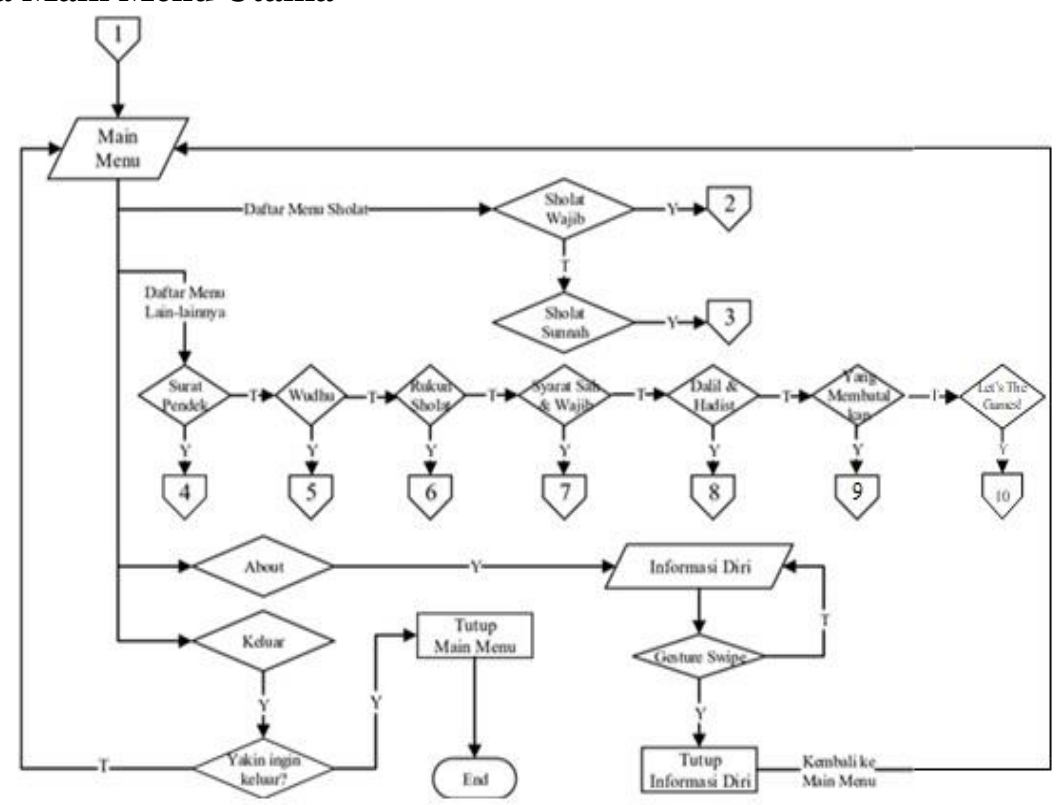

Gambar 2. Flowchart Pada Main Menu Utama

Pada Perancangan Aplikasi Pengenalan Macam-macam Sholat Sunnah, Tata Cara dan Juz'ama ini, peneliti membuat desain pada aplikasi dengan menggunakan rancangan struktur navigasi dan flowchart. Berikut ini adalah tampilan aplikasi pada Aplikasi Pengenalan Sholat Sunnah, Tata Cara dan Juz'ama :

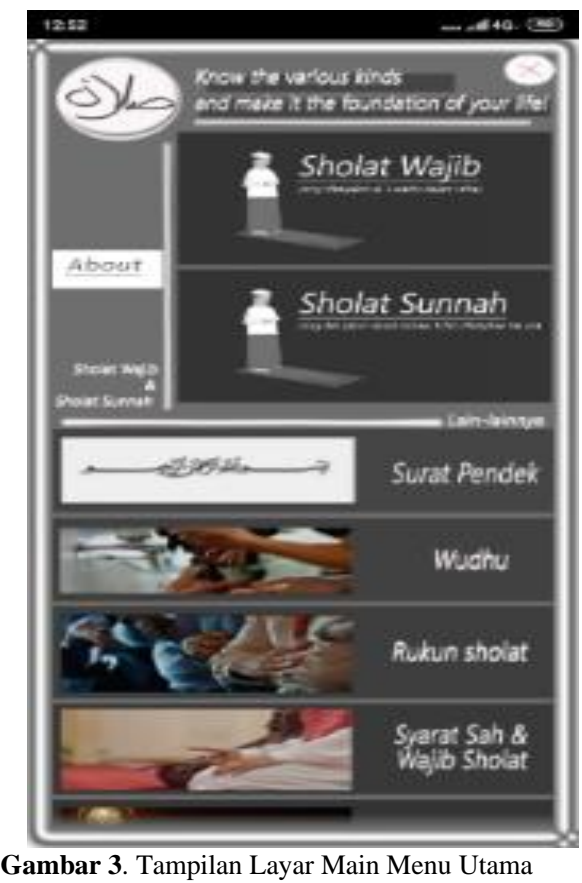

Tampilan main menu utama ini terdapat beberapa menu yang akan menampilkan aksi ataupun informasi-informasi yang dibutuhkan, seperti sebagai berikut:

a. Pada daftar menu sholat terdapat tombol pilihan menu sholat wajib dan sholat sunnah yang akan menampilkan informasi-informasi dan sub menu di dalamnya.

b. Pada daftar menu lain-lainnya terdapat fungsi scrollable untuk menggulir pilihan tombol menu seperti surat pendek untuk menampilkan informasi sub menu dari surat pendek.

c. Tombol menu wudhu jika di pilih akan menampilkan informasi dan tata cara berwudhu. 
d. Dalam daftar menu lain-lainnya juga terdapat tombol menu rukun sholat, syarat sah \& wajib sholat, dalil \& hadist, yang membatalkan sholat jika dipilih hanya akan menampilkan informasi di dalamnya.

e. Tombol menu time to game?! jika dipilih akan memulai permainan baru dengan quiz random (soal acak) saat pertama kali dimainkan, dan akan mendapatkan skor nilai dari poin yang didapat setelah menyelesaikan permainannya.

f. Tombol about jika dipilih akan menampilkan informasi dari pembuat aplikasi.

g. Tombol X pada pojok kanan atas dalam tampilan main menu utama berfungsi untuk keluar pada aplikasi.

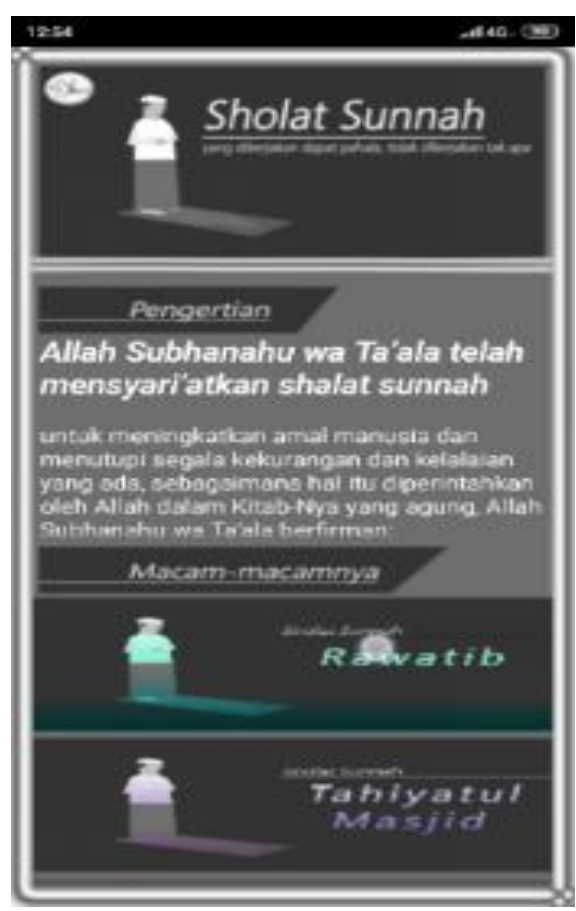

Gambar 4. Tampilan Layar Menu Sholat Sunnah

Tampilan diatas merupakan tampilan menu sholat wajib dan sholat sunnah. Di dalamnya terdapat informasi seputar sholat sunnah dan tombol sub menu yang jika di pilih akan menampilkan lagi menu yang didalamnya terdapat seputar informasi dan tombol video tuntunan sholat terkait.

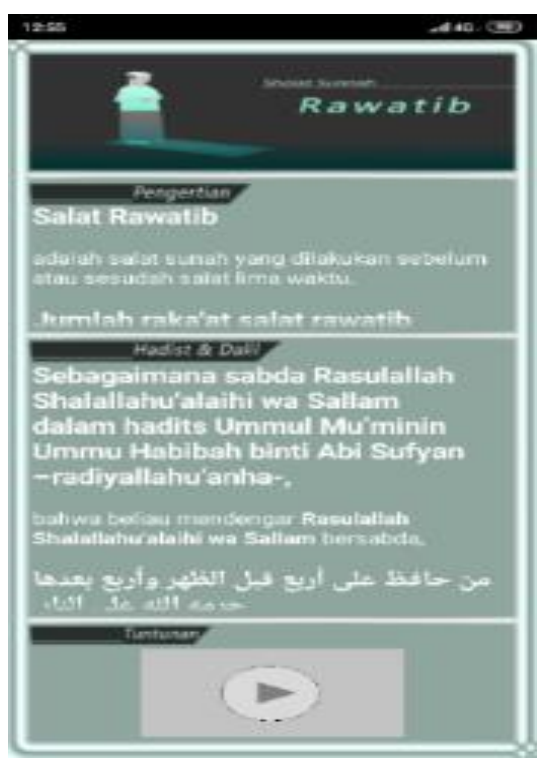

Gambar 5. Tampilan Layar Menu Sholat Rawatib yang dipilih pada sub menu Sholat Sunnah 
Tampilan diatas adalah tampilan menu sholat rawatib yang dipilih dalam sub menu sholat sunnah, di dalamnya terdapat informasi seputar sholat rawatib dan tombol aksi video untuk menampilkan video tuntunan pada sholat terkait.

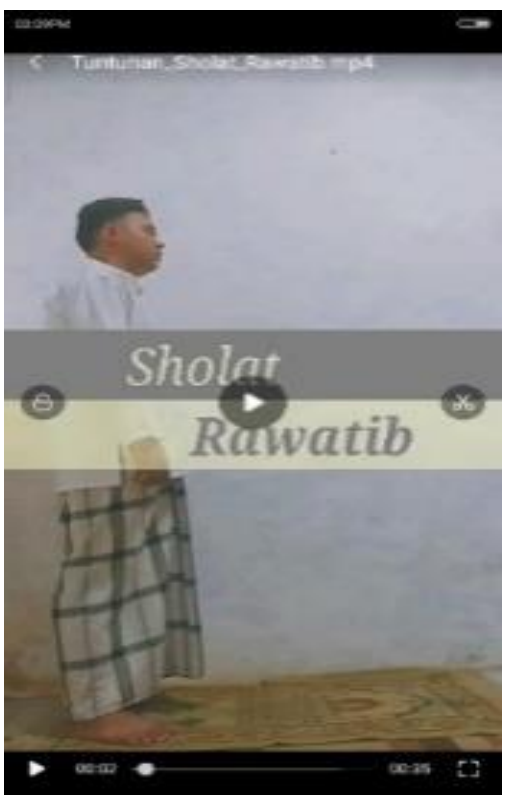

Gambar 6. Tampilan Layar Video Tuntunan Sholat Rawatib

Tombol aksi video jika pilih akan menampilkan video tuntunan sholat rawatib.

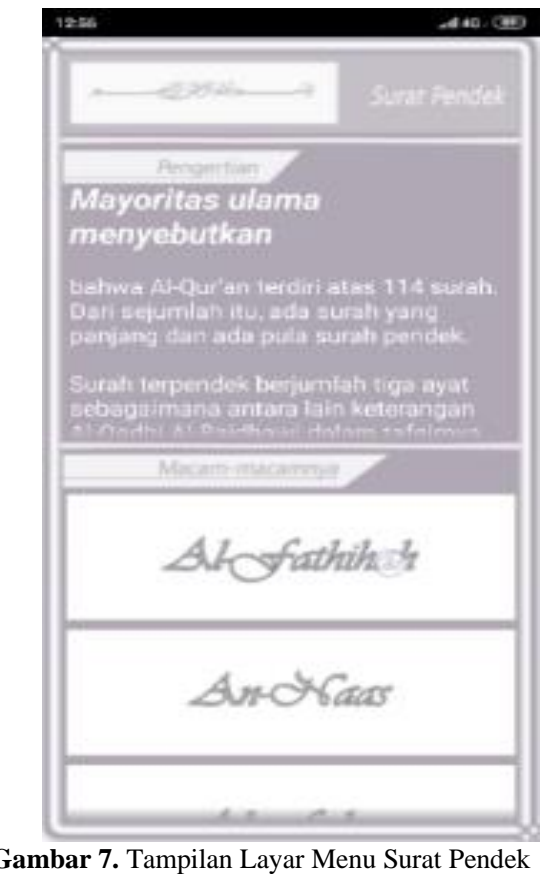

Tampilan diatas adalah tempilan menu surat pendek yang didalamnya terdapat informasi-informasi seputar surat pendek dan sub menu tombol pilihan surat pendek. Jika tombol dipilih maka akan menampilkan bacaan surat pendek terkait dan tombol aksi audio untuk memutarkan suara surat terkait 


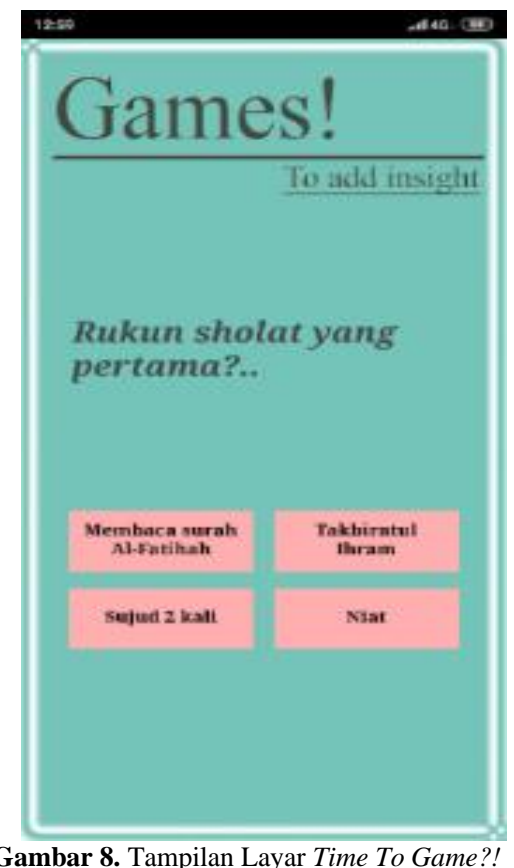

Tampilan diatas terdapat permainan soal acak. Jika tombol time to game?! dalam daftar menu lainlainnya dipilih maka akan tampil permainan dengan pilihan ganda seputar sholat sunnah dan agama islam.

\section{SIMPULAN}

Dengan dibuatnya aplikasi android Pengenalan Macam-macam Sholat Sunnah, Tata Cara dan Juz'ama ini diharapkan dapat membantu khususnya pada anak-anak ataupun masyarakat awam untuk lebih mengenal dan mengetahui banyaknya macam-macam sholat sunnah dan hal-hal yang berikaitan penting untuk melengkapi syarat dari pelaksanaakannya pada ajaran agama islam, dengan penyajian informasi yang efesien dan efektif bagi penggunanya.

\section{DAFTAR PUSTAKA}

H. Cahya, Lesmana; R. Rizal, Isnanto; W. Didik, E. (2016). Perancangan Aplikasi Android "SHOLAT YUKK" Sebagai Media Pembelajaran Ibadah Shalat Anak-Anak. Teknologi Dan Sistem Komputer, 4 (4).

Jogiyanto, H. (2010). Definisi Analisis dan Sistem Informasi. In Analisis \& Desain Sistem Informasi (III). Andi Offset.

Kirana, H. (2010). Pengertian Implementasi. http://cenil19.blogspot.com/2010/05/pengertian-implementasi.html

Mukhadis. (2016). Definisi Evaluasi. In Evaluasi Program Pembelajaran Bidang Teknologi. Bayumedia Publishing.

Nanda Samsu Dhuha. (2018). “Apa yang dimaksud dengan Pengujian perangkat lunak atau Software Testing?" https://www.dictio.id/t/apa-yang-dimaksud-dengan-pengujian-perangkat-lunak-atau-software-testing/15136

Nazruddin. (2012). Pengertian Android. In Pemrograman Aplikasi Mobile Smartphone dan Tablet PC berbasis android. (p. 1). Informatika Bandung.

Nuryanto Joko. (2018). Aplikasi Shalat Pada Smartphone Berbasis Android. Islam Negri Jakarta.

O’Brien dan Marakas. (2010). Definisi Perancangan. In Management Information Systems (Eighth Edi, p. 619). McGrewHill/Irwin.

Sugiyono. (2013). Definisi Desain Penelitian. In Metode Penelitian Kuantitatif, Kualitatif dan R\&D (Alfabeta.C, p. 2).

Sumantri, A. (2011). Definisi Penelitian. In Metode Penelitian Kesehatan Edisi Pertama (p. 6). Kencana.

Susano, A. (2016). Rancang Bangun Aplikasi Berbasis Android Untuk Pengolahan Data Pengurus Masjid. Indraprasta PGRI.

Sutabri, T. (2012). Pengertian / Definisi Android. In Analisis Sistem Informasi (p. 147). Andi Offset.

Yolanda, B. (2017). Aplikasi Tuntunan Shalat Berbasis Android. Univesitas Pamulang. 